\title{
Prototype of a new tip developed to be coupled to dental light-curing units for optimizing bonding of orthodontic brackets and accessories
}

\author{
Sergio Luiz Mota Júnior¹, Márcio José da Silva Campos², Marco Abdo Gravina3, Marcelo Reis Fraga4, \\ Robert Willer Farinazzo Vitral ${ }^{5}$
}

Objective: development of a new device to be coupled to light-curing units for bonding orthodontic brackets and accessories, and test its efficacy in an in vitro mechanical trial. The inner surface of the device is mirrored and is based on physical concepts of light refraction and reflection. The main advantage of such device is the reduced clinical time needed for bonding and the low possibility of contamination during the process. Methods: One hundred and twenty specimens were used for testing the shear bond strength of brackets bonded with the device. The Adhesive Remnant Index (ARI) was also determined. The sample was divided into 2 groups. In group 1 a halogen light-curing unit was used while in group 2 a led light-curing unit was used. Each group was then subdivided. In subgroups H1 and L1, a conventional light guide rod was used while in subgroups H2 and L2 bonding was performed with the mirrored device coupled to the tip of the guide light rod. Results: The values obtained for the shear bond strength and the ARI in the subgroups were compared. Results showed that there was no statistically significant difference for the shear strength $(p>0.05)$ and the ARI $(p>0.05)$ between the subgroups. Conclusion: The tests of mechanical trials and the ARI analysis showed that the new device fulfilled the requirements for bonding orthodontic accessories, and that the time for bonding was reduced to half, being necessary only one light exposure.

Keywords: Light-curing of dental adhesives. Orthodontic brackets. Patents. Shear strength.

Objetivo: desenvolver uma nova ponteira para ser acoplada aos aparelhos fotopolimerizadores utilizados para colagem de braquetes e acessórios ortodônticos, e testar sua da efetividade em ensaio mecânico in vitro. A ponteira é espelhada na superfície interna e baseia-se em conceitos físicos de refração e reflexão de luz. Apresenta como principal vantagem o menor tempo clínico durante o procedimento de colagem, reduzindo a possibilidade de contaminação durante o processo. Métodos: por meio de ensaio de resistência ao cisalhamento e determinação do índice remanescente de adesivo (IRA), testou-se a ponteira desenvolvida em 120 corpos de prova. A amostra foi dividia em dois grupos. No grupo 1, foi utilizado aparelho fotopolimerizador de fonte de luz halógena e, no grupo 2, fonte de LED. Cada grupo foi subdividido. Nos subgrupos H1 e L1, utilizou-se a ponteira convencional. Nos subgrupos H2 e L2 a colagem foi feita utilizando a ponteira desenvolvida para a polimerização do material de colagem. Resultados: os valores dos testes de cisalhamento e IRA para os subgrupos foram comparados entre si. Os resultados mostraram que não houve diferença estatisticamente significativa para o ensaio de resistência ao cisalhamento $(p>0,05)$ nem para o IRA $(p>0,05)$ entre os subgrupos. Conclusão: os testes de ensaio mecânico, assim como a análise do IRA, mostraram que a nova ponteira desenvolvida cumpriu os requisitos necessários à colagem dos acessórios ortodônticos, e que o tempo de colagem foi reduzido pela metade, sendo necessária uma só incidência.

Palavras-chave: Braquetes ortodônticos. Cura luminosa de adesivos dentários. Patentes. Resistência ao cisalhamento.

\footnotetext{
' PhD Student in Health, Federal University of Juiz de Fora (UFJF).

${ }^{2}$ Post-Doctorate Student in Health,UFJF. Professor of the graduate program in Orthodontics, UFJF.

${ }^{3} \mathrm{MSc}$ in $\mathrm{PhD}$ in Orthodontics, State University of Rio de Janeiro (UERJ). Associate professor of Orthodontics, School of Dentistry, and professor of the graduate program in Orthodontics, UFJF.

${ }^{4} \mathrm{MSc}$ in Orthodontics, Pontifical Catholic University of Minas Gerais (PUC$M G)$. Doctorate student in Health, UFJF. Professor of the graduate program in Orthodontics, UFJF.

${ }^{5}$ Associate professor and program director of the graduate program in Orthodontics, UFJF.
}

How to cite this article: Mota Júnior SL, Campos MJS, Gravina MA, Fraga MR, Vitral RWF. Prototype of a new tip developed to be coupled to dental lightcuring units for optimizing bonding of orthodontic brackets and accessories. Dental Press J Orthod. 2013 Nov-Dec;18(6):112-6.

Submitted: September 19, 2011 - Revised and accepted: October 03, 2011

" The author reports no commercial, proprietary or financial interest in the products or companies described in this article.

Contact address: Sergio Luiz Mota Júnior

Rua Humaitá, 10 - Apto 303 - Juiz de Fora /MG - CEP: 36.016-150 - Brazil

E-mail: sergiomotajr_orto@yahoo.com.br 


\section{INTRODUCTION}

The light-emitting sources for light curing of composite resins that are available in the market are halogen lamps, blue light-emitting diodes (LEDs), argon laser and xenon plasma arc. ${ }^{3,20}$ Although the latter reduce curing time to one quarter ${ }^{23}$ and one third, ${ }^{24}$ respectively, in comparison to that afforded by conventional curing units, the machines are costly, which hampers their use in private dental offices. ${ }^{23,24}$

LED is the acronym for Light-Emitting Diode, a semiconductor diode which, when energized, emits visible light through luminescence and not through a heated filament, consuming less power and producing less heat. ${ }^{18,19,20}$ Halogen light curing units have been replaced by LED units ${ }^{2,18}$ due to its small number of components and lower power consumption. ${ }^{6,18}$

In Orthodontics, bonding brackets and accessories is time-consuming ${ }^{3}$ and humidity control is difficult, which may lead to contamination of the enamel surface and consequent bonding failure. ${ }^{21}$

Based on the present conditions for bonding brackets and orthodontic accessories, combined with concepts of Optical Physics, this study aimed at developing and testing a new model of curing unit-adjusted tip, with the purpose of reducing time, achieving better quality and reducing power consumption during the bonding procedure in Orthodontics.

\section{MATERIAL AND METHODS}

Based on the existing models of curing units, of which tip contains an optical fiber filament, we developed a mirrored concave tip, based on the fact that spherical concave mirrors are polished caps which are reflective in their inner surfaces. The tip we developed (Fig 1A - upper view, 1B - lateral view) is adjusted to the tips of conventional curing units (Fig 2).

The filing of the patent application was registered with the National Institute of Industrial Property (Instituto Nacional da Propriedade Industrial - INPI) under the number 020110074054.

The Committee of Ethics in Animal Experimentation of the Federal University of Juiz de Fora (UFJF) approved this research project (protocol $\mathrm{n}^{\mathrm{o}}$ 025/2010).
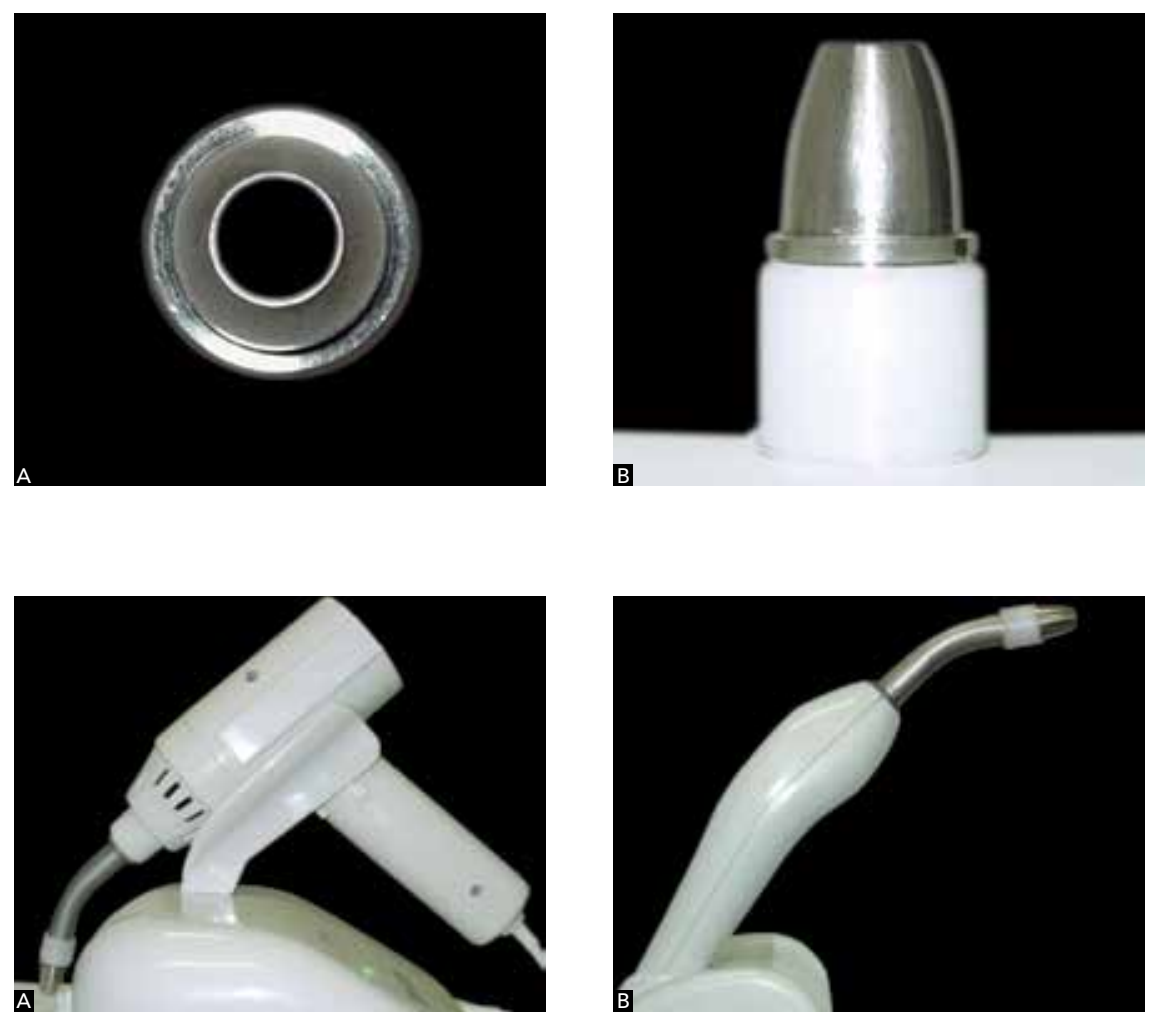

Figure 1 - A) Upper view, B) Lateral view of the new developed tip

Figure 2 - A) Halogen light curing unit with coupled tip; B) LED curing unit with coupled tip. 
In order to assess the performance of the tip in orthodontic bonding, we carried out the mechanical trial of shear bond strength and the analysis of the adhesive remaining index (ARI) due to their morphological and histological similarity to human teeth, 120 bovine mandibular incisors were used in this in vitro study. ${ }^{11,17,22}$ The teeth were selected with a stereomicroscope (Stemi $2000-$ C, Zeiss), at the Modern Physics Department of the Sciences Institute of the Federal University of Juiz de Fora (UFJF).

Two groups of 60 teeth each were formed. Group 1 comprised teeth of which bracket bonding was performed with a halogen-light curing unit (Dabi Atlante Ultralux), while for group 2, a LED-source curing unit (Dabi Atlante Ultraled) was used. Each group was subdivided in 2 subgroups, with 30 teeth each. In subgroups $\mathrm{H} 1$ and L1, the conventional tip was used, while in subgroups $\mathrm{H} 2$ and L2 the experimental tip we developed was used.

Bracket bonding was performed according to the instructions of the manufacturer of the composite resin (3M Transbond $\mathrm{XT}^{\circledR}$ ). 120 brackets were used (Dental Morelli, reference 10.30.201).

In subgroup $\mathrm{H} 1$, the mesial and the distal surfaces were exposed to light for 10 seconds each. In subgroup L1, the mesial and distal surfaces were exposed to light for 5 seconds each. Light exposure was $10 \mathrm{sec}-$ onds in subgroup H2 and 5 seconds in subgroup L2. Bonding in group 1 happened with the light held 5 $\mathrm{mm}$ away from the bracket-tooth interface, with an incidence parallel to the bonding surface. In group 2, the tip was positioned so as to embrace the bracket in a single incidence.

The bodies of proof for testing shear resistance were assembled ${ }^{15}$ in a Universal Testing Machine, EMIC - DL 10000, equipped with a 50Kgf Trd 21 load cell, software Tesc version 3.04 of the Military Institute of Engineering- Rio de Janeiro - LEM $\mathrm{DE} / 4$. After the mechanical trial was performed, the ARI for each body of proof was determined with the Stemi 2000 - C stereomicroscope (Zeiss). The ARI indices were classified into 4 scores, ${ }^{1}$ as shown in Table 1.

\section{RESULTS}

Table 2 shows mean values and standard deviation of each subgroup (H1, H2, L1 and L2).
Student's t test was used for comparison between subgroups. The $\mathrm{p}$ value for comparison between H1-H2 and L1-L2 was 0.365 and 0.176 , respectively, thus, showing no statistically significant difference between the subgroups.

Figure 3 shows the distribution of values regarding the shear resistance test between groups.

The ARI distribution for each group is shown in Figure 4. The Kruskal-Wallis test was used for ARI statistical analysis. With $\mathrm{p}>0.05$, no statistically significant difference between groups was found.

\begin{tabular}{|c|c|}
\hline \multicolumn{2}{|c|}{ ARI - Adhesive Remaining Index } \\
\hline Score & Frequency of remaining adhesive \\
\hline 0 & No adhesive remaining on the dental enamel \\
\hline 1 & Less than half of the adhesive remaining on the dental enamel \\
\hline 2 & More than half of the adhesive remaining on the dental enamel \\
\hline 3 & $\begin{array}{l}\text { The entire adhesive remaining on the enamel, with distinct } \\
\text { impression of the bracket mesh }\end{array}$ \\
\hline
\end{tabular}

Table 2 - values of shear resistance tests in $\mathrm{MPa}$.

\begin{tabular}{ccc}
\hline Subgroup & $\mathbf{n}$ & Mean \pm SD \\
\hline H1 & 30 & $9.89 \pm 5.36$ \\
\hline H2 & 30 & $9.01 \pm 5.61$ \\
L1 & 30 & $7.01 \pm 4.26$ \\
\hline L2 & 30 & $7.63 \pm 5.48$ \\
\hline Total & 120 & \\
\hline
\end{tabular}

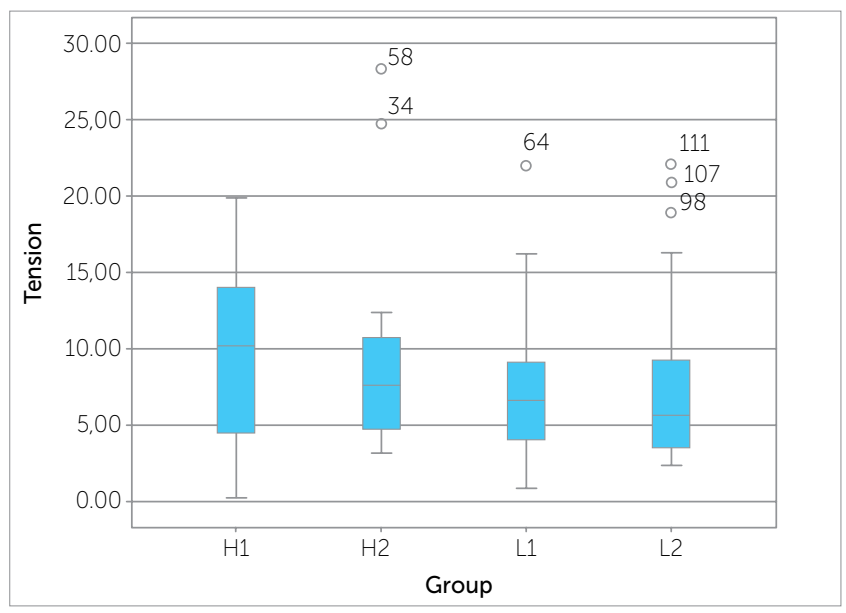

Figure 3 - Box plot diagram of shear resistance in MPa for each subgroup. 


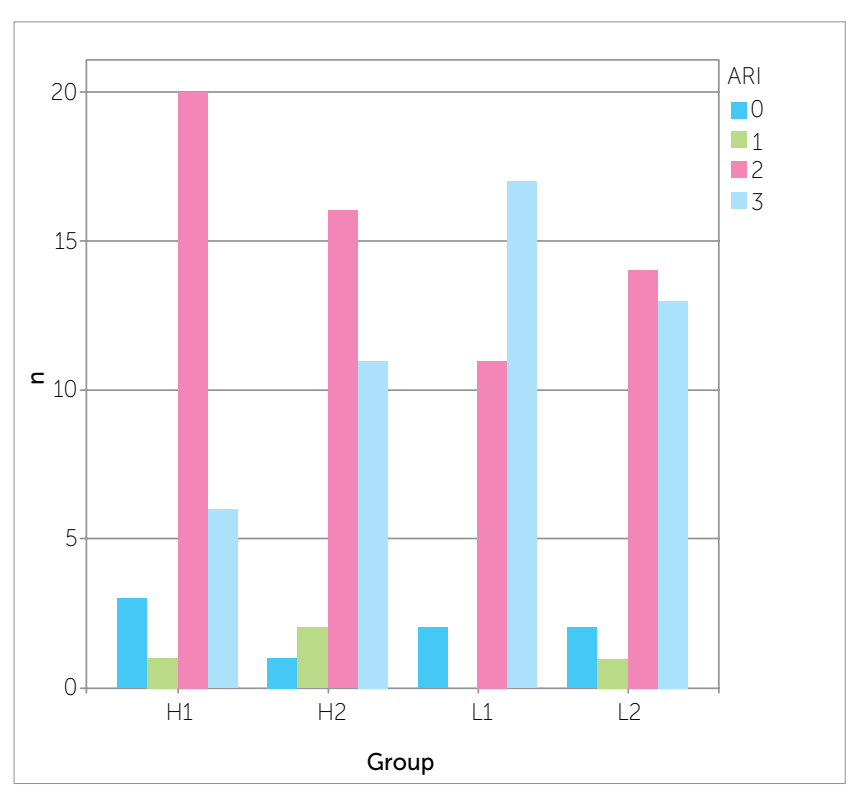

Figure 4 - Bar chart for each group, with regard to ARI incidence.

\section{DISCUSSION}

Aiming at reducing orthodontic bonding time, we developed a tip that can be coupled to curing units. This device is based on the concepts of curing unit light refraction and reflection. When visible light reaches the end of the optical fiber of the curing unit, it changes from one medium (optical fiber) to another (air), and the light ray is refracted into a medium with a lower refractive index. This refracted ray is no longer dissipated across the medium, but reflected by the inner mirrored wall of the new device. Because the new tip converges towards the bracket-tooth end, the light rays reach the composite resin in the mesial, distal, incisal/occlusal and gingival directions simultaneously, which reduces curing time up to $1 / 4$ of the time recommended by the manufacturer of traditional tips.

One of the disadvantages of using light-curing composite resins is the high number of steps that are necessary during bonding, which increases working time and the likelihood of errors and contamination during the procedure. $5,7,10,12,13,14,16 \mathrm{~W}$ ith the new tip, bonding time was reduced, consequently reducing errors caused by saliva contamination.

For subgroups H1 and L1, variation of light exposure time was in accordance with the recommendations given by the manufacturer of the $3 \mathrm{M}$ Transbond $\mathrm{XT}^{\circledR}$ composite resin, while for subgroups $\mathrm{H} 2$ and $\mathrm{L} 2$ it was half the time proposed by the manufacturer. The recommended times are: 20 seconds for an halogen source (10 seconds for the mesial surface and 10 seconds for the distal surface) and 10 seconds for a LED source (5 seconds for the mesial surface and 5 seconds for the distal surface).

Bond resistance corresponds to bond strength divided by the bonding interface area $\left(\mathrm{mm}^{2}\right)$. The bracket/adhesive system must resist to a minimum force of $6 \mathrm{MPa}$ (megapascal) to be considered clinically successful. $4,8,9,14$ All groups in this study had a mean value greater than what is required for orthodontic success.

As for the ARI assessment, the Kruskal-Wallis test showed no statistically significant difference between groups ( $p>0.05)$. The majority of bodies of proof from each subgroup scored 2 or 3 , with most of the adhesive remaining on the enamel surface, thus indicating that rupture occurred in the adhesive/bracket interface and not in the enamel/adhesive interface, as expected after adequate light curing.

Therefore, the shear test results and the ARI results proved both bonding techniques, either carried out with the conventional tip or with the tip developed in this study to be efficient.

\section{CONCLUSIONS}

1 - Both the mechanical trials and the ARI analysis showed that the new tip met the necessary requirements for bonding orthodontic accessories;

2 - Bonding time was reduced by half, and only a single incidence was necessary. 
1. Årtun J, Bergland S. Clinical trials with crystal growth conditioning as an alternative to acid-etch enamel pretreatment. Am J Orthod. 1984:85(4):333-40.

2. Barghi N, Fischer DE, Pham T. Revisiting the intensity output of curing lights in private dental offices. Compend Contin Educ Dent. 2007:28(7):380-4

3. Bishara SE, Gordan VV, VonWald L, Olson ME. Effect of an acidic primer on shear bond strength of orthodontic brackets. Am J Orthod Dentofacial Orthop. 1998;114(3):243-7.

4. Bishara SE, VonWald L, Laffoon JF, Jakobsen JR. Effective of altering the type of enamel conditioner on the shear bond strength of a resinreinforced glass ionomer adhesive. Am J Orthod Dentofacial Orthop. 2000;118(3):288-94

5. Bishara SE, Laffoon JF, Vonwald L, Warren JJ. The effect of repeated bonding on the shear bond strength of different orthodontic adhesives. Am J Orthod Dentofacial Orthod. 2002;121(5):521-5.

6. Bullough JD. LED lighting systems. Lighting Answers. NLPIP. 2003 [Acesso 15 set 2011];7(3):1-23. Disponivel em: http://www.Irc.rpi.edu/ programs/nlpip/lightingAnswers/led/abstract.asp.

7. Cacciafesta V, Sfondrini MF, Baluga L, Scribante A, Klersy C. Use of a self-etching primer in combination with a resin-modified glass ionomer effect of water and saliva contamination on shear bond strength. Am J Orthod Dentofacial Orthop. 2003:124(4):420-6

8. Cacciafesta V, Sfondrini MF, Barina E, Scribante A, Garino F, Klersy C. Effect of different light sources and guide on shear bond strength of brackets bonded with 2 adhesives systems. Am J Orthod Dentofacial Orthop. 2005:128(1):99-102

9. Cacciafesta V, Sfondrini MF, Calvi D, Scribante A. Effect of fluoride application on shear bond strength of brackets bonded with a resin-modified glass-ionomer. Am J Orthod Dentofacial Orthop. 2005:127(5):580-3.

10. Cacciafesta V, Sfondrini MF, Scribante A, De Angelis M, Klersy C. Effect of blood contamination on shear bond strength of brackets bonded with a self-etching primer combined with a resin-modified glass ionomer. Am J Orthod Dentofacial Orthop. 2004:126(6):703-8

11. Campos MIC, Campos CN, Vitral RWF. O uso de dentes bovinos como substitutos em dentes humanos em pesquisas odontológicas: uma revisão de literatura. Pesq Brasil Odontop Clin Odontol. 2008:8(1):127-32.

12. Correr Sobrinho L, Correr GM, Consani S, Sinhoreti MAC, Consani RLX. Influência do tempo pós-fixação na resistência ao cisalhamento de bráquetes colados com diferentes materiais. Pesqui Odontol Bras 2002:16(1):43-9
13. Dominguez GC, Tortamato A, Carvalho PAL, Bomfim RA, Horliana RF, Vigorito JW. Self-etching primer: resistência confiável na colagem de acessórios ortodônticos? Estudo clínico. Ortodontia SPO 2005:38(1):10-5

14. Dorminey JC, Dunn WJ, Taloumis LJ. Shear bond strength of orthodontic brackets bonded with a modified 1-step etchand-and-primer technique. Am J Orthod Dentofacial Orthop. 2003;124(4):410-3.

15. Dutra GAA, Rocha JM, Fraga MR, Vitral RWF. Avaliação comparativa in vitro da resistência à força de cisalhamento apresentada pelo bráquete ceramico InVu. Pesq Bras Odontoped Clin Integr. 2009;9(2):173-9.

16. Eliades T, Eliades G, Brantley WA, Johnston WM. Polymerization efficiency of chemically cured and visible light-cured orthodontic adhesives: degree of cure. Am J Orthod Dentofacial Orthop. 1995;108(3):294-301.

17. Fonseca RB, Haiter-Neto F, Fernandes-Neto AJ, Barbosa GA, Soares CJ. Radiosensity of enamel and dentin of human, bovine and swine teeth. Arch Oral Biol. 2004;19(11):912-22.

18. Onofre NML, Retamoso LB, Marchioro EM, Berthold TB. Atuação da luz halógena e do LED (light emitting diode) na resistência de união de brackets colados no esmalte dentário humano. Rev Odonto Ciênc 2007:22(57):238-42.

19. Owens BM, Rodriguez KH. Radiometric and spectrophotometric analysis of third generation light-emitting diode (LED) light-curing units J Contemp Dent Pract. 2007:8(2):43-51.

20. Rueggeberg FA. State-of-the-art: Dental photocuring - A review. Dent Mater. 2011:27(1):39-52

21. Sayinsu K, Isik F, Sezen S, Aydemir B. Effect of blood and saliva contamination on bond strength of brackets bonded with a protective liquid polish and a light-cured adhesive. Am J Orthod Dentofacial Orthop. 2007:131(3):391-4.

22. Saleh F, Taymour N. Validity of using bovine teeth as a substitute for human counterparts in adhesive tests. East Mediterr Health J. 2003; 9(1-2):201-7.

23. Talbot TQ, Blankenau RJ, Zobitz ME, Weaver AL, Lohse CM, Rebellato J. Effect of argon laser irradiation on shear bond strength of orthodontic brackets: an in vitro study. Am J Orthod Dentofacial Orthop. 2000:118(3):274-9

24. Thind BS, Stirrups DR, Lloyd CH. A comparison of tungsten-quartzhalogen, plasma arc and light-emitting diode light sources for the polymerization of an orthodontic adhesive. Eur J Orthod $2006: 28(1): 78-82$ 